\title{
Evaluation of alcohol concentrations in samples referred to the forensic Laboratory in Baghdad
}

Muataz Abdulmajeed Al-Qazzaz ${ }^{1 *}$, Atheer Jawad Al-Saffar ${ }^{2}$, Hayder Khadum Al-Rubai ${ }^{3}$ and Enas Muataz Al-Qazzaz ${ }^{4}$

\begin{abstract}
Background: Detection of alcohol in postmortem blood and body fluids is of extreme importance in medico-legal investigation as it may affect and change the decision of the court in legal hearing. It can be a cause death or sharing a role in different modes of death.
\end{abstract}

Objectives: To evaluate the problem of alcohol intake in general and its relation to age,sex and its contribution in different causes of death.

Method: A prospective study within 6 month period on postmortem blood samples referred to the lab. For detection and measurement of alcohol.

Five to $10 \mathrm{ml}$ of blood of each sample was tested using Head Space GC with flame ionization detector (FID) from Agilent 7890A.

Result: In general traumatic death was predominant among all victims.From total 1275, only 112 (8.8\%) sample were positive. Males were more than 5 times than females.

There was a significant relation of alcohol intake with traumatic causes of death, yet only in 13 victims the concentration was fatal.

Conclusion: Alcohol drinking is a minor problem as it was detected in a small group of all cases yet its association with traumatic death was significantly higher than natural death and its consumption was more than 5 times in males. Only in limited number of cases the concentration was fatal.

Keywords: Alcohol, Postmortem, Ethanol, Autopsy

\section{Introduction}

Alcohol is a social drug. It is one of the world's leading risk factors for morbidity,mortality and disability. In 2012, 5.9\% of all global deaths were attributed to alcohol and $5.1 \%$ of all global burden of diseases and injuries were attributed to its use as well. Its effect was more pronounced from neuropsychiatric disorders (Global Status Repost on Alcohol and Health, 2014).

Annually 88,000 people die from alcohol-related causes in USA and it is considered the fourth leading preventable cause of death. It is blamed to $31 \%$ of all driving fatalities and in 2014 it was found that $59.8 \%$ of

\footnotetext{
* Correspondence: m_zq88@hotmail.com

${ }^{1}$ Department of Pathology and Forensic Medicine, College of Medicine,

University of Al-Nahrain, PO Box 70028, Baghdad, Iraq

Full list of author information is available at the end of the article
}

college students ages 18- 22 years drank alcohol during the month prior to the study (National Institute on Alcohol Abuse and Alcoholoism, n.d.).

In England, there were 1,059,210 patients admitted to hospitals due to diseases or injuries related to alcohol consumption during the years $2013-2014$ and the highest were due to cardiovascular diseases and alcohol liver diseases. It was also found that men had drunk normal strength beer while the majority of women had drunk wine (Statistics on Alcohol, England, 2015).

The CDC (Communicable Diseases Control) links excessive alcohol use to many health risks such as RTA (Road Traffic Injuries), firearm injuries, domestic violence, child abuse syndrome, suicide and some other diseases like hypertension, heart disease, cancer and personality 
disorders (Impact of alcoholism and Alcohol Induced diseases on America, 2011; Zhu et al., 2009).

In Iraq there is no legal level of alcohol that permits working or driving under its effect and any positive sample is considered as an illegal offence.

Problematic alcohol uses among military personnel such as psychological impairment and Post-Traumatic Stress Disorders (PTSD) were also noted following combat military experiences. Marines and Navy branches of military services were more likely to report heavy alcohol drinks (Schumm \& Charad, n.d.).

Alcohol is also related to many crimes. In 2013 $-2014,53 \%$ of violent crimes were under the effect of alcohol, these include assaults, wounds, sexual offences, homicide, criminal damage, theft and robbery (Snowdon, n.d.).

Psychiatric diseases and symptoms are also related to chronic alcohol use ranging from anxiety, bipolar disorders to frank schizophrenia (Hashimoto et al., 2013).

\section{Objectives of the study}

1- To detect the presence of alcohol and its concentration in all samples of autopsy cases referred to the lab.

2- To classify them according to age, sex, month of the year and the type of alcohol ingested.

3- To classify the postmortem samples according to the mode of death and verify its contribution to the cause of death.

\section{Methods}

A prospective study on 1275 postmortem samples for alcohol detection in blood was carried out. Blood samples were sent to the main forensic alcohol lab. of the Medico-legal Directorate in Baghdad during the second half of the year 2015 after approval by the Ethical approval committee. These samples were withdrawn from the heart of fresh autopsy cases by the forensic pathologist for alcohol detection and measurement of its concentration (Kugelberg \& Jones, 2007).

Each samples contains $5-10 \mathrm{ml}$ of blood in test tube containing $1 \%$ sodium fluoride to prevent fermentation by bacteria.

Only $2.5 \mathrm{ml}$ of blood were used from each sample to detect alcohol,its type and measure its concentration using headspace gas chromatography (HS-GC) with automated sampling using flame ionization detector (FID) from Agilent 7890A Network Gas Chromatography with Capillary Flow Technology.

Each $100 \mu \mathrm{L}$ of blood sample was diluted 10 times with a known concentration of aqueous solution of internal standard (which was prepared by dissolving sodium chloride in distilled water then added to propanol) and the blood sample and the internal standard were immediately ejected into a glass vial which was fitted with a Teflon-lined stopper and air tightened to be ready for $\mathrm{HS}$ analysis .

The concentration of alcohol in the unknown blood sample was found by interpolation using computer software and a linear regression analysis by comparing the peak area ratio for alcohol to internal standard and the known concentration of alcohol in the standard (Moffat et al., 2011). Four points of calibration curve were adopted $(0.4,0.8,1.2$ and $1.6 \mathrm{mg} \%)$. The cut-off point of alcohol is $40 \mathrm{mg} / 100 \mathrm{ml}$, below this level the sample was considered negative as it may be due to postmortem bacterial decomposition and any value above 40 is considered to be positive sample.

\section{Results}

During the six months selected for analysis, samples of 1275 deaths with autopsy exam were included in the

Table 1 Socio-demographic characteristics, cause of death and alcoholic status of the sample

\begin{tabular}{|c|c|c|}
\hline Variable & Frequency & Percent \\
\hline \multicolumn{3}{|l|}{$\overline{\text { Age (years): }}{ }^{a}$} \\
\hline$<25$ & 156 & 12.3 \\
\hline $25-34$ & 317 & 24.9 \\
\hline $35-44$ & 304 & 23.9 \\
\hline $45-54$ & 257 & 20.2 \\
\hline$\geq 55$ & 238 & 18.7 \\
\hline Mean \pm SD & $40.1 \pm 13.1$ & \\
\hline \multicolumn{3}{|l|}{ Sex: } \\
\hline Females & 139 & 10.9 \\
\hline Males & 1136 & 89.1 \\
\hline \multicolumn{3}{|c|}{ Month of death: } \\
\hline July & 165 & 12.9 \\
\hline August & 326 & 25.6 \\
\hline September & 232 & 18.2 \\
\hline October & 176 & 13.8 \\
\hline November & 210 & 16.5 \\
\hline December & 166 & 13.0 \\
\hline \multicolumn{3}{|c|}{ Cause of death: } \\
\hline Natural & 261 & 20.5 \\
\hline Traumatic & 1014 & 79.5 \\
\hline \multicolumn{3}{|l|}{ Alcohol status: } \\
\hline Negative & 1163 & 91.2 \\
\hline Positive & 112 & 8.8 \\
\hline Mean \pm SD & $249.4 \pm 102.8$ & \\
\hline Total & 1275 & 100.0 \\
\hline
\end{tabular}


study. They were of mean \pm SD age of $40.1 \pm 13.1$ years ranged between 14 and 72 years old, male to female ratio was 8.2: 1 , the highest rate of death happened during August month 326 (25.6\%), and only one fifth of them was natural deaths $261(20.5 \%)$ and the remaining had traumatic source. Positive alcohol consumption was found in $112(8.8 \%)$ of the all deaths with mean \pm SD alcohol concentration in their blood was $249.4 \pm$ $102 \mathrm{mg} / 100 \mathrm{ml}$ with a range between 55 and $583 \mathrm{mg} /$ $100 \mathrm{ml}$ and one death was methanol rather than ethanol consumption was detected.

The study failed to find significant relation between consumption of alcohol among the victims and their age, their sex, and the month when the death happened. However, a highly significant relation was found with cause of death as those died traumatically had higher consumption $P=0.007$ (Table 1 and 2).

Out of 112 positive alcohol results 13 samples were $400 \mathrm{mg} / 100 \mathrm{ml}$ and above.

Regarding the relation of the cause of death with the studied variables, the study found a significant relation $P=0.001$ with the victim age as traumatic death decrease with increasing age, highly significant relation $P=0.00001$ with victim sex as females had more traumatic source of death than males $(91.4 \%$ versus 78.1\% respectively) making male to female traumatic death ration to reach $1: 1.17$, while no relation was found with the month when the death happened (Table 3).

Further description of 112 deaths with positive alcohol consumption revealed that their mean \pm SD age was41.5 \pm 14.1 years. Male to female ratio was 5.6: 1 . August was also the month with the highest rate of death36 (32.1\%), and only $12(10.7 \%)$ deaths was of natural causes among this group, with traumatic to natural deaths ratio among males and females was 10.9:1 and 3.25:1 respectively.

\section{Discussion}

Detection and Measurement of alcohol concentration is very important in forensic examination as it may affect and change the decision of the court in legal hearing.

The study aimed to reveal the impact of alcohol consumption in medico-legal autopsy examination.

The study was conducted within 6 months period (2nd half of the year 2015).

Because of known connection of alcohol to trauma and the order of the investigation authorities, many blood samples were withdrawn from autopsy cases

Table 2 Relation of alcohol consumption with the studied variables

\begin{tabular}{|c|c|c|c|c|c|c|}
\hline \multirow[t]{3}{*}{ Variable } & \multirow{3}{*}{$\begin{array}{l}\text { Total } \\
\text { No. }\end{array}$} & \multicolumn{4}{|c|}{ Alcohol Consumption } & \multirow[t]{3}{*}{ Significance } \\
\hline & & \multicolumn{2}{|l|}{ Positive } & \multicolumn{2}{|l|}{ Negative } & \\
\hline & & No. 112 & Percent 8.8 & No. 1163 & Percent 91.2 & \\
\hline \multicolumn{7}{|l|}{ Age (years): } \\
\hline$<25$ & 156 & 13 & 8.3 & 143 & 91.7 & \multirow{6}{*}{$\begin{array}{l}X^{2}=0.69 \\
d f=4 \\
P=0.95\end{array}$} \\
\hline $25-34$ & 317 & 27 & 8.5 & 290 & 91.5 & \\
\hline $35-44$ & 304 & 27 & 8.9 & 277 & 91.1 & \\
\hline $45-54$ & 257 & 21 & 8.2 & 236 & 91.8 & \\
\hline$\geq 55$ & 238 & 24 & 10.1 & 214 & 89.9 & \\
\hline Total & 1272 & 112 & 8.8 & 1160 & 91.2 & \\
\hline \multicolumn{7}{|l|}{ Sex: } \\
\hline Females & 139 & 17 & 12.2 & 122 & 87.8 & \multirow{2}{*}{$\begin{array}{l}X^{2}=2.31 \\
d f=1 \\
P=0.128\end{array}$} \\
\hline Males & 1136 & 95 & 8.4 & 1041 & 91.6 & \\
\hline \multicolumn{7}{|c|}{ Month of death: } \\
\hline July & 165 & 11 & 6.7 & 154 & 93.3 & \multirow{6}{*}{$\begin{array}{l}X^{2}=4.93 \\
d f=5 \\
P=0.43\end{array}$} \\
\hline August & 326 & 36 & 11.0 & 290 & 89.0 & \\
\hline September & 232 & 23 & 9.9 & 209 & 90.1 & \\
\hline October & 176 & 11 & 6.2 & 165 & 93.8 & \\
\hline November & 210 & 17 & 8.1 & 193 & 91.9 & \\
\hline December & 166 & 14 & 8.4 & 152 & 91.6 & \\
\hline \multicolumn{7}{|c|}{ Cause of death: } \\
\hline Natural & 261 & 12 & 4.6 & 249 & 95.4 & \multirow{2}{*}{$\begin{array}{l}X^{2}=7.18 \\
d f=5 \\
P=0.007\end{array}$} \\
\hline Traumatic & 1014 & 100 & 9.9 & 914 & 90.1 & \\
\hline
\end{tabular}


Table 3 Relation of type of death with the studied variables

\begin{tabular}{|c|c|c|c|c|c|c|}
\hline \multirow[t]{3}{*}{ Variable } & \multirow{3}{*}{$\begin{array}{l}\text { Total } \\
\text { No. }\end{array}$} & \multicolumn{4}{|c|}{ Type of death } & \multirow[t]{3}{*}{ Significance } \\
\hline & & \multicolumn{2}{|l|}{ Natural } & \multicolumn{2}{|l|}{ Traumatic } & \\
\hline & & No. 261 & Percent 20.5 & No. 1014 & Percent 79.5 & \\
\hline \multicolumn{7}{|l|}{$\overline{\text { Age (years) }{ }^{a} \text { : }}$} \\
\hline$<25$ & 156 & 25 & 16.0 & 131 & 84.0 & \multirow{6}{*}{$\begin{array}{l}X^{2}=19.196 \\
d f=4 \\
P=0.001\end{array}$} \\
\hline $25-34$ & 317 & 55 & 17.4 & 262 & 82.6 & \\
\hline $35-44$ & 304 & 52 & 17.1 & 252 & 82.9 & \\
\hline $45-54$ & 257 & 57 & 22.2 & 200 & 77.8 & \\
\hline$\geq 55$ & 238 & 71 & 29.8 & 167 & 70.2 & \\
\hline Total & 1272 & 260 & 20.4 & 1012 & 79.6 & \\
\hline \multicolumn{7}{|l|}{ Sex: } \\
\hline Females & 139 & 12 & 8.6 & 127 & 91.4 & \multirow{2}{*}{$\begin{array}{l}X^{2}=13.43 \\
d f=1 \\
P=0.00001\end{array}$} \\
\hline Males & 1136 & 249 & 21.9 & 887 & 78.1 & \\
\hline \multicolumn{7}{|c|}{ Month of death: } \\
\hline July & 165 & 31 & 18.8 & 134 & 81.2 & \multirow{6}{*}{$\begin{array}{l}X^{2}=4.99 \\
d f=5 \\
P=0.42\end{array}$} \\
\hline August & 326 & 56 & 17.2 & 270 & 82.8 & \\
\hline September & 232 & 47 & 20.3 & 185 & 79.7 & \\
\hline October & 176 & 39 & 22.2 & 137 & 77.8 & \\
\hline November & 210 & 51 & 24.3 & 159 & 75.7 & \\
\hline December & 166 & 37 & 22.3 & 129 & 77.7 & \\
\hline
\end{tabular}

There were 3 missing age value

referred the medico-legal directorate in Baghdad and sent to alcohol toxicology lab. For screening.

Most of the victims were young adults and middle age group and this is the usual and most common age for drinking (Li et al., 2017).

The vast majority of the victims were males and this was expected due to their intense engagement in different work activities including heavy and harsh jobs in every aspects in a stressful environment which ultimately make them more exposed to various types of fatalities.

Traumatic causes of death were prevailing due to many factors such as stress, overcrowding streets and poor traffic control, different accidents, terrorist attacks, difficult socioeconomic circumstances as well as social and family problems resulting in violent behavior (Al-Qazzaz et al., 2012).

The highest number of death was during August probably because it is the hottest month of the year in the country and probably in the world as the temperature may exceeds $50{ }^{\circ} \mathrm{C}$,moreover poor and interrupted power supply increasing both natural and traumatic causes of death.

Positive samples were only almost $9 \%$ as it is expected in Islamic country where Islam considers drinking alcohol is haraam (forbidden in Islam) in addition to lack of bars.

All of them were ethanol which is the usual type of alcohol for drinking and only one sample result was methanol probably because it is cheaper and more available and the victim was unaware of its toxic effect (Karadenis et al., 2011).

The study found a highly significant relation between consumption of alcohol and traumatic death as it is a well known fact that drinking alcohol increases the impact of trauma,RTA, the risk of crimes, violent behavior promoting homicide or even suicide due to personality disorders (Impact of alcoholism and Alcohol Induced diseases on America, 2011; Zhu et al., 2009; Schumm \& Charad, n.d.; Snowdon, n.d.; Hashimoto et al., 2013).

Only in 13 samples of traumatic causes of death alcohol concentrations were $400 \mathrm{mg} / 100 \mathrm{ml}$ and above. These concentrations are considered fatal alone regardless of their trauma due to depression of respiratory center (Di Maio \& Di Maio, 2001).

The study also revealed that traumatic causes of death decreased significantly with advancing age which seems to be logic as violence and exposure to trauma are more seen in young adult and middle age groups where physical fitness and activities are stronger while older age group prefer to stay more at home and retired.

In general higher numbers of female were seen to be affected by trauma compared to male, this could be explained to be due to exposure to domestic violence, poor driving skill and domestic injuries and the protective effect of female sex hormones that lessen their natural 
death. Positive male samples were more than 5 times than positive female samples, this is due to our social traditions refusing any women drinking alcohol and consider it stigma against her as well as our Islamic commitment.

Only 12 positive samples were attributed to natural causes of death. In those victims alcohol probably was sharing their diseases in precipitating death. Regarding the positive group (112 deaths), the study showed more traumatic causes of death in male than what was seen in female due to the effect of alcohol on male individual behavior and attitude in addition to the previously mentioned factors (Thompson, 1996).

\section{Conclusion}

Alcohol drinking is a minor problem as it was detected in a small group of all cases yet its association with traumatic death was significantly higher than natural death and was more common in males. Traumatic death was more common in females. The study also revealed that traumatic causes of death decreased significantly with advancing age.

Only in limited number of cases the concentration was fatal.

\section{Acknowledgments}

The authors present their gratitude and appreciation to the staff of forensic toxicology department and alcohol lab. For their cooperation to complete the study.

\section{Funding}

Self funding

\section{Availability of data and materials}

Supporting data is available when needed.

\section{Declaration}

Ethical approval and consent to participate was obtained from the Ethical Approval Committee of College of Medicine- University of Al-Nahrain.

\section{Authors' contributions}

MAA-Q: Introduction, method and discussion. AJA-S: Statistical analysis and results. HkA-R: Collection of data. EMA-Q: Detection and measurement of alcohol using head space GC. All authors read and approved the final manuscript.

\section{Ethics approval and consent to participate}

Ethical approval was gained from the Ethical Approval Committee /College of Medicine /University of Al-Nahrain.

\section{Consent for publication}

Author and co-authors do accept publication of the research paper.

\section{Competing interests}

The authors declare that they have no competing of interests.

\section{Publisher's Note}

Springer Nature remains neutral with regard to jurisdictional claims in published maps and institutional affiliations.

\section{Author details}

${ }^{1}$ Department of Pathology and Forensic Medicine, College of Medicine, University of Al-Nahrain, PO Box 70028, Baghdad, Iraq. ${ }^{2}$ Department of
Community Medicine, College of Medicine, University of Al-Nahrain, Baghdad, Iraq. ${ }^{3}$ Forensic DNA Centre for Research and Training, Baghdad, Iraq. ${ }^{4}$ Forensic Alcohol Lab., Medico-legal Directorate, Baghdad, Iraq.

Received: 15 June 2017 Accepted: 12 November 2017

Published online: 15 December 2017

\section{References}

Al-Qazzaz M, Al-Khateeb N, Al-Jouboory S (2012; April) Medicol-legal study on natural deaths. The New Iraqi J Med 8(1), p 21-26

Di Maio VJ, Di Maio D (2001) Chapter 23. In: Interpretive toxicology, drug abuse, drug death, forensic pathology, 2nd edn. CRC Press, Boca Raton London New York Washington DC, pp 519-557

Global Status Repost on Alcohol and Health, 2014, WHO Library Cataloguing-inPublication Data, p 1-376

Hashimoto E, Riederer PF, Hesselbrock VM, Hesselbrock MN, Mann K, UkAI W, Soma H, Thibaut F, Schuckit MA, Saito T (2013) Consensus paper of the WFSBP task force on biological marker : biological marker for alcoholism. World J Biol Psychiatry 14:549-564

Impact of alcoholism and Alcohol Induced diseases on America, Research Society on Alcoholism, April, 2011

Karadeniz H. and Birincioglu I., Methyl alcohol poisoning in Trabzon (Turkey), J Forensic Sci, May,2011; vol.56,no.3

Kugelberg FC, Jones AW (2007) Interpreting results of ethanol analysis in postmortem specimens. Forensic Sci Int 165:10-29

Li R, Hu L, Hu L, Zhang X, Philipps R, Fowler DR, Chen F, Li L (2017) Evaluation of acute alcohol intoxication as a primary cause of death : a diagnostic challenge for forensic pathologist. J Forensic Sci 62(5):1213-1219

Moffat AC, David OM, Widdop B, Watts J (2011) Chapter 4, driving under the influence of alcohol. In: Clarke's analysis of drugs and poisons, vol 1, Fourth edn, pp 87-114

National Institute on Alcohol Abuse and Alcoholoism, www.niaaa.nihgov.301. 443.3860

Schumm JA, Charad KM Alcohol and stress in the military. Alcohol Research : Current Reviews. 34(4):401-405

Snowdon D, Alcohol-Related Crimes, Alcohol and the Public Purse, Do Drinking Pay their way? IEA Discussion Paper n. 63

Statistics on Alcohol, England 2015, Health and Social Care, Information Centre 25 June, 2015

Thompson $J$ (1996) Mental disease in a forensic autopsy population of alcoholics. Sci Justice 36:89-92

Zhu L, Sun J, Wood P (2009) Statistical methods for analysis of alcohol and drug uses for young adults. J Data Sci 7:469-485

\section{Submit your manuscript to a SpringerOpen ${ }^{\mathcal{O}}$ journal and benefit from:}

- Convenient online submission

- Rigorous peer review

- Open access: articles freely available online

- High visibility within the field

- Retaining the copyright to your article

Submit your next manuscript at $>$ springeropen.com 